\title{
Laboratory Test Sequence Number
}

National Cancer Institute

\section{Source}

National Cancer Institute. Laboratory Test Sequence Number. NCI Thesaurus. Code C83314.

An identifier that describes the relative position of laboratory test data within a series. 